\title{
Headaches in the elderly, in an out-patient population over 60 years of age
}

\author{
E Venturelli*, R Rao, S Gipponi, P Liberini, A Padovani \\ From The European Headache and Migraine Trust International Congress \\ London, UK. 20-23 September 2012
}

Headache in community-living adults age 65 and older is the 10th most common reported symptom in women and the 14th most common in men. Although the prevalence of headache declines with age, approximately $10 \%$ of women and $5 \%$ of men at age 70 experience severe recurrent or constant headaches. Much less is known about the evolving clinical profile of migraine over the life span. The present study aimed to investigate every type of headaches in elderly people and was carried out on a group of patient over 60 years of age, selected from 771 consecutive patients to the Headache Centre in the period January 2011-December 2011.

\section{Methods}

This study was conducted in a university-based outpatient headache clinic. The study population consisted of 771 consecutive headache patients treated by the authors in one year. Variables studied included gender, headache duration in years, aura, headache characteristics, associated symptoms, presence of allodynia, headache frequency, headache days, and disability. Amedical history of these patients was also recorded. The headache diagnosis were made according to ICHD-2 criteria. Patients were stratified by age into 3 groups: group 1, 16 to 39 , group II, 40 to 59 , and group III, 60 years and older.

\section{Results}

A total of 605 patients were female and 166 were male, mean age was $36.9+13.6$ years (range 16 to 84 ), average headache duration 18.4 years, and headache days/month 7.9. The average age of older headache suffers was 66.5 years. There were 48 female patients $(7.9 \%)$ and 6 male patients $(3.6 \%)$ in the older age group. There were no differences between the groups in gender and other variables assessed. The $60+$ age group tended to have

Neurological Clinic Headache Center Spedali Civili University of Brescia, Italy more chronic migraine and to use more acute medication. Discussion In our population chronic migraine and medication overuse don't decline over time. We found that, compared with younger patients, older headache patients had not a "lesser migraine" as reported in previous studies. Studies of community-based headache population are warranted to define the influence of age on the full spectrum of migraine.

Published: 21 February 2013

\section{References}

1. Edmeads J: Headaches in the elderly. Headaches. 3 edition. Lippincott Williams \& Wilkins; 2006.

2. Lipton RB, Stewart WF, et al: Prevalence and burden of migraine in the United States: data from the American Migraine Study II. Headache 2001, 41:646-657.

3. Prencipe $M$, Casini AR, Ferretti $C$, et al: Prevalence of headache in an elderly population: attack frequency, disability, and use of medication. J Neurol Neurosurg Psychiatry 2001, 70:377-381.

doi:10.1186/1129-2377-14-S1-P229

Cite this article as: Venturelli et al:: Headaches in the elderly, in an outpatient population over 60 years of age. The Journal of Headache and Pain 2013 14(Suppl 1):P229.

Submit your manuscript to a SpringerOpen ${ }^{\odot}$ journal and benefit from:

- Convenient online submission

- Rigorous peer review

- Immediate publication on acceptance

- Open access: articles freely available online

- High visibility within the field

Retaining the copyright to your article

Submit your next manuscript at $>$ springeropen.com 